\title{
VOICES AGAINST SOCIO-POLITICAL INEQUALITY IN CRITICAL DISCOURSE ANALYSIS
}

\author{
Huynh Anh Tuan* \\ Faculty of Post-Graduate Studies, VNU University of Languages and International Studies, \\ Pham Van Dong, Cau Giay, Hanoi, Vietnam
}

Received 25 March 2017

Revised 14 May 2017; Accepted 19 May 2017

\begin{abstract}
This paper reviews critical discourse analysis (CDA) research in the fields of media, politics, racism and sexism discourse with voices raised against socio-political inequality, which is also one of the fundamental goals CDA has been attempting to attain. Literature review shows that CDA research describing and criticizing socio-political inequality through language use is enormous and so is its impact on individuals and groups as members of our conflicting society. CD analysts, using emancipatory discourse, can contest the maintenance and reproduction of domination and subordination patterns in society through language practices by raising people's awareness of the asymmetrical relation of power.
\end{abstract}

Keywords: CDA, socio-political inequality, media discourse, political discourse, racism, sexism

\section{Introduction}

The fight for social equality is inarguably one of the most humanitarian and noblest causes carried out by human beings since the coming into existence of social classes. It is the creation and defence of group's as well as individual's authority and interest that perpetuate the power struggle, which takes place in various forms from the tangible battles with cannonballs to the more subtle arenas in political debates. It seems paradoxical that the more civilized and developed a society is, the more fierce its members' effort to balance the power. In the modern society where the sound of fire guns and bombs has calmed down in some parts of the world, the voices against injustice in the ideological and cultural forums have not in the least. Voices raised against social inequality in language use have brought about a perspective of viewing and analyzing

* Tel.: 84-902229101

Email: huynhanhtuan@vnu.edu.vn language: Critical Discourse Analysis (CDA), "particularly associated with the work of the British socio-linguist Norman Fairclough and has become particularly influential in Europe and Australia" (Trask, 2007:61). CDA has been defined in various ways revealing the approach, methods, goals, and fields of research by such pre-eminent authors as Fairclough (1992), Janks \& Ivanič, (1992), Tannen, (1994; 2003), Coulthard (1995; 1996), Schäffner (1996), Kendall \& Tannen, (1997), Wodak (1997), Baranov (1998), Cameron (1998), Thomas \& Wareing (1999), Wodak (2000), Widdowson (2000), Wodak \& Reisigl (2001), Van Dijk (2001), Talbot, Atkinson \& Atkinson (2003), Litosseliti (2006), among many others. Van Dijk (2001:352)'s description of CDA is assuredly considered as capturing the essence of CDA in which "CDA is a type of discourse analytical research that primarily studies the way social power abuse, dominance, and inequality are enacted, reproduced, and resisted by text and talk in the social and political context. Critical discourse 
analysts take explicit position, and thus want to understand, expose, and ultimately resist social inequality". Holding aloft the banner of socio-political equality are critical discourse analysts whose contribution to social balance is undeniable.

\section{CDA goals}

As a whole, the resistance against sociopolitical injustice in language use undertaken by $\mathrm{CD}$ analysts is the supreme target of CDA, which can comprise the following specific sub-goals:

- "Make people more socio-politically aware of the way language is used to manipulate them" (Widdowson, 2000: 9);

- "Understand, expose, and ultimately resist social inequality" (Van Dijk 2001: 352);

- "Act upon the world in order to transform it and thereby help create a world where people are not discriminated against because of sex, creed, age or social class" (Caldas-Coulthard 1996, cited in Widdowson 2000: 155);

- "Understand social issues, inequalities, and ideologies, by exposing the subtle role of discourse in maintaining them (the "hidden agenda" of discourse)" (Litosseliti 2006: 3);

- "Illuminate the specific mechanisms through which dominance/subordination - elements which structure society as a whole - are produced in daily life" (Räthzel, cited in Wodak 1997: 57);

- "Develop more effective means against persecution" (Räthzel, cited in Wodak 1997: 57);

- Deconstruct and reconstruct images of the other (Räthzel, cited in Wodak 1997: 78);

- "Describe and explain, and if necessary criticize (changing) social and discursive practices, based on solid research" (Schäffner 1996: 5);

Van Dijk (2001: 355) poses two basic questions for CDA research:

1. How do (more) powerful groups control public discourse?

2. How does such discourse control mind and action of (less) powerful groups and what the social consequences of such control, such as social inequality?

In order to find answers to these two basic questions, $\mathrm{CD}$ analysts often ask themselves the following questions in analyzing a specific text: 'Why was this text constructed at all?' 'To whom is it addressed, and why?' 'Does the writer or speaker have concealed purposes, and, if so, what are they?' 'What hidden assumptions and biases underlie the text?' (Trask, 2007:61). In view of the subgoals specified and the questions asked to achieve the goals, whether or not the goal of "making people more socio-politically aware of the way language is used to manipulate them" is seen as fairly summarizing the goals of CDA depends on how the attributive "socio-politically" and the broadened meaning of "aware" is perceived. The term "society" may inherently encompass all the other components as sexism, racism, ethno-centrism, anti-semitism, nationalism, etc., which in turn integrate themselves into politics. Language itself forms part of society; language use including its syntactic and pragmatic discursive features may well be considered as indispensable cells of social life. Though provoking controversy at different levels regarding the extent to which it acts upon human beings, the impact of language on their mind and action is generally acknowledged. Language awareness naturally entails changing language practices, which are "closely tied with changes in social relationships and with changing social 
identities" (Fairclough, 1992: 4). Therefore, in a way, Widdowson's remark can be said to have solidified the goals of CDA. In this paper, our aim is basically to explore how far CDA has contributed to the global movement of criticizing power imbalance, the ultimate goal as pointed out by Van Dijk, Räthzel, and Widdowson, specifically in the fields of media, politics, racism and sexism discourse.

\section{The Criticality of CDA}

CDA is critical in that it views discourse as a form of social practice and criticizes the way discourse reproduces socio-political inequality, power abuse or domination. That is the reason why CDA is considered part of critical linguistics and critical language awareness. Critical linguistics is a linguistic approach acknowledging the rhetorical potential of texts in influencing social beliefs, values and expectations. Critical language awareness is the educational policy of teaching people to be alert to socio-political issues, which can be critical in some aspects including linguistic matters (Trask, 2007). Perspectives which can be more or less critical can be found in other linguistic fields and approaches such as pragmatics, conversation analysis, narrative analysis, rhetoric, stylistics, sociolinguistics, ethnography, or media analysis, among others (Van Dijk, 2001), i.e, the critical element in the analysis is not exclusive to CDA.

\section{Fundamental issues and typical terms in CDA}

The fundamental issues in CDA rooted in the typical terms centering on CDA research are power, power abuse, dominance, and ideology.

Fundamental and central to the discussions in most critical studies is the notion of power, more specifically the social power of groups or institutions, defined in terms of control.
Groups or institutions are considered to have power if they can control the acts and minds of other groups. This controlling ability 'presupposes a power base of privileged access to scarce social resources, such as force, money, status, fame, knowledge, information, culture, or indeed various forms of public discourse and communication' (Van Dijk, 2001:354-355). In that line of thought, power abuse is the violation of "laws, rules and principles of democracy, equality and justice" by those people who have more power (Van Dijk, 1993:255).

Dominance is defined as "the exercise of social power elites, institutions or groups, that results in social inequality, including political, cultural, class, ethnic, racial and gender inequality" (Van Dijk, 1993:249-50).

Ideology in CDA is the set of beliefs underlying an utterance or discourse. Ideologies can be conscious, subconscious or unconscious in the form of ideas, beliefs, goals, expectations, and motivations, etc. which can be held by an individual or shared by a group or society. Every example of language in use has 'an ideological dimension'... 'An utterance that describes an event in the world has to choose one of the many possible lexicogrammatical ways in which that event can be encoded' (Trask, 2007: 113). In other words, no instance of language use is neutral in ideology.

\section{Language and ideology/power relationship}

Power, power abuse, dominance, and ideologies are encoded in different linguistic forms, often at the lexico-grammatical levels, which might include the optional use of either active or passive voice, focusing on one topic rather than another, foregrounding one perspective rather than another, choosing particular naming or address patterns rather than others, selecting a level for formality, register, politeness, and so on. Trash (2007) 
affirmed that choices of lexico-grammatical devices encode ideological dimensions. One single and the same real-world event of sociopolitical life can be linguistically encoded in different ways revealing different ideologies. In the following headlines, different ideologies are encoded by different linguistic forms, such as the implicit assignment of blame and the shifting of emphasis. Hidden in the ways various lexico-grammatical devices are utilized to construct the headlines of the same event (the shooting of the police at the demonstrators in a demonstration) are different ideologies which can manipulate the readers' views of the event by either (implicitly) exalting or defaming the agents or the victims involving the event.

- Police shoot demonstrators (active voice, explicit assignment of blame on the agents, implicitly revealing the reporter's stance against the police and the ruling Party and in favour of the demonstrators/the opponent Party)

- Demonstrators are shot (passive voice, avoiding ascribing responsibility for the action of shooting to the implicit agents, implicitly revealing the reporter's stance in favour of the police and the ruling Party and against the demonstrators/the opponent Party )

- Shooting at demo (neither the agents nor victims of the action mentioned, implicitly revealing the reporter's sitting-on-the-fence's stance)

- Demo ends in violencel 2 dead at demo (neither the agents nor the victims of the action mentioned with emphasis on the result of the action, implicitly revealing the reporter's sitting-on-thefence's stance)

- Police make arrests as 2 die in demo riot (active voice, explicit assignment of blame on the agents, however, the agents' responsibility is shifted to another less violent action of arresting with the agents' the more violent action of shooting causing death is kept hidden). (Trask, 2007: 61).

So why does CDA depict as its principal objective the task of deciphering the interrelationship between ideology/power and discourse and to regain social equality? The explanation can be partially traced back to the struggle for survival, of which gaining power and balancing human relationships are perhaps the most crucial activities. However, the power games in our society are so subtle that sometimes even the players are not always aware of their existence and they tend to take myriads of power exertion instances for granted. Power manipulation may be disguised in various intangible apparels so much so that even the most conscious people may stand a chance of not recognizing its impact. In terms of language communication, the multi-layer of discourse interactions implies numerous aspects of power abuse very likely to be invisible to participants who by no or little means are capable of fully sensing its influence on their participation. This embraces every feature of discourse as genres, topics and speech acts, etc. and also the channels of communication from the media to everyday settings and the various subtypes of discourse (courtroom, bureaucratic, medical, educational and scholarly). A university professor may use his or her power to force students into taking what he/she says as an uncontroversial truth. A student, on the other hand, due to his/her lack of knowledge in the specific field, finds himself/herself vulnerable to his/her supervisor or tutor's remark (Wodak, 1987). Both of them are broadening the gap of inequality in discourse without realizing that they are doing so. Nevertheless, CDA's function in raising people's awareness in language encounters is not at all an easy job in that it aims at ameliorating social reality 
without breaking its discourse conventions, which are what construct and stabilize social structure. Furthermore, power abuse varies according to ethnic communities and the knowledge level of the citizens of a specific society. In a way, we are all being manipulated by language use. People in societies where awareness of equality has long been established may be more sensitive to imbalance in power than those being the citizens of nations where power distribution inequilibrium is taken as a matter of fact and part of social norms. What is more, the impoverishment in some underdeveloped or developing countries have pushed their people into ignoring big issues as political power to give priority to more practical everyday concerns as finding food and clothes. Some people are inclined to reluctance in touching the problem especially among people of different social groups. Essed (1991: 67) exemplified the phenomenal tendency in one of his studies: "It has been shown repeatedly that Black informants are reticent about discussing their experiences of White racism with a White interviewer." To approach the matter from political perspectives, injustice, unfortunately and ridiculously predominates in western countries where political leaders at all times promulgate the slogan of freedom, equality and humanity. Power dominance in political discourse has been analyzed in several researches such as by Baranov (1998) and many other authors (see Chilton et al. 1998). The paradox with CDA is that it seems not to be publicly and extensively mentioned or rather not allowed to flourish in social systems in countries where its role is more significant in the fight for the liberty of speech, which is restricted and to some extent, persecuted. All of these may be the explanations for CDA's goals as expressed by Widdowson and other $\mathrm{CD}$ analysts. It is no exaggeration in the least to say that to enhance individual awareness of the sociopolitical injustice in power is to prepare for a futuristic society of more equality, democracy and civilization. All what the human race has done so far can be assumed to fundamentally serve that everlasting purpose.

\section{CDA voices against socio-political inequalities}

CD analysts have carried out research largely in the field of sexism (gender inequality) and racism, media discourse and politics discourse. Other fields of research include: Ethnocentrism, Antisemitism (ideologies against the Jewish, Arabian, Assyrian, \& Phoenician), and Nationalism. In this paper, CDA works are summarized in the most typical fields of CDA: media and politics discourse; racism and sexism, the fields of CDA research which aim at fighting for equality in human socio-political life.

\subsection{CDA voices against socio-political} inequalities in media and political discourse

In the discourses of the media, politicians, leaders of political Parties, the spoke-person of a ruling or opponent Party's use of language may potentially exalt their values of ideology and implicitly defame their opponents' by referring to themselves as 'we' the civilized world, the 'free democracies', 'the West', 'the free world', in contrast with 'the other' Eastern countries, where the terrorists may come from (Trash, 2007). The metonymic processes of referring underlying this bipolarization or dichotomy may manipulate people's view of the world as a world of binary division, as Chilton (1998) suggested, 'whereby one element (the USA) stands for another entity - a supposed collectivity labelled "free democracies", whose real world reference however, is not determinate', but excludes or classifies negatively the 'others' (Caldas- 
Coulthard, 2003: 272). The dominant values of the ideology providing criteria for evaluation of forms of behaviour in the press are presented in Chibnall (1977:21-22) as follows.

$\begin{array}{cc}\begin{array}{c}\text { Positive } \\ \text { legitimating values } \\ \text { Legality }\end{array} & \begin{array}{c}\text { Negative } \\ \text { legitimating values } \\ \text { Illegality }\end{array} \\ \text { Extremism } & \text { Moderation } \\ \text { Compromise } & \text { Dogmatism } \\ \text { Cooperation } & \text { Confrontation } \\ \text { Order } & \text { Chaos } \\ \text { Peacefulness } & \text { Violence } \\ \text { Intolerance } & \text { Tolerance } \\ \text { Constructiveness } & \text { Destructiveness } \\ \text { Openness } & \text { Secrecy } \\ \text { Corruption } & \text { Honesty } \\ \text { Realism } & \text { Ideology } \\ \text { Rationality } & \text { Irrationality } \\ \text { Bias } & \text { Impartiality } \\ \text { Fairness } & \text { Unfairness } \\ \text { Firmness } & \text { Weakness } \\ \text { Industriousness } & \text { Idleness } \\ \text { Freedom of choice } & \text { Monopoly/uniformity } \\ \text { Equality } & \text { Inequality }\end{array}$

When Western countries construct their images using the positive legitimating values, they at the same time potentially depict the others, the Eastern countries as having the negative values, which are inherently associated with wrongdoings and problems. Raising people's awareness about this bipolarization or dichotomy tendency in the language of the media, $\mathrm{CD}$ analysts have contributed to reshaping existing acquiescence to such unfounded and unfair bipolarization.

\subsection{CDA voices against socio-political} inequalities in racism and sexism

Power relations are not only reflected in physical settings but also in verbal struggles. Individuals or groups' language production reflects their ideologies in the power struggles in which language is used or even abused as a weapon protecting their privileges oppressing the less powerful others (Räthzel, 1997). 'It is through discursive interaction that meanings are produced and transmitted, that institutional roles are constructed and power relations developed and maintained' Wodak (2000:185). CDA has contributed to the global movement of criticizing power imbalance, especially in the fields of racism and sexism in language use. CD analysts suggest that people are who they are (partly) because of the way they use language (Cameron, 1998). In the interface between language awareness and language use, language awareness naturally entails changing language practices, which are "closely tied with changes in social relationships and with changing social identities' (Fairclough, 1992:4). Racism and sexism as hidden in language use are not just individual opinions about and prejudices against others but rather "social structures of oppression” (Räthzel, 1997:59).

An overview of recent research in racism and sexism might offer an estimate of how far CDA has been into achieving the goals set up. Racism and sexism are issues that interest not only researchers of the fields but also laymen whose everyday life is inevitably under the impact of these social ideologies. There have been numerous analytical researches into racist and sexist ideologies, e.g. Räthzel (1994; 1997). In 1994, Räthzel carried out a survey investigating her students' ideological association of the 4 terms: German women, Turkish women, German men, and Turkish men. The findings were very interesting revealing many crucial issues in DA such as collectivity and individuality, interrelation of gender and ethnicity, patriarchy and class relations, constructions of the other as rebellious self-subordination, the homogenous other and the complex self, deconstruction and reconstruction of the other's images (Trash, 2007). In her studies, Räthzel found out that 
the ways of subordination of the two groups of women within the family and in relation towards men are opposed to each other. German women are seen as subordinating themselves actively, while Turkish women are depicted as being the victims of men, of their nature and of ideologies. What counts as important in all of these studies is that they render not only valuable findings but also suggest some extremely implications regarding the awareness and response of individuals as participants of the social power games. Räthzel (1997: 78), in her conclusion to the German and Turkish survey, suggested "in order to transform power relations it is not enough for individuals to reposition themselves as agents of social change and deconstruct their images of the other; however, in not doing this, the attempt to get rid of racism and sexism might merely reproduce them in a more subtle way". Research into racism and sexism has been continuously done to illuminate the real mechanism of language use in the two socio-political fields.

\subsubsection{Racism in Language}

Racism as one of the most sensitive social issues has attracted the interest of quite a few CDA researchers. The term racism itself has become familiarized with everybody no matter what their genetic origins are and has expanded its omnipresent status in this ever-increasing intercultural world as today when people are more and more aware of racism and its impact on the construction and reconstruction of human perspectives on judging other people. Its appearance in discourse has increased in significance as discourse analysts more and more recognize its profound influence on social life, exceptionally in association with politics where it is used as a weapon to defend or to fight for social rights. The term "race" can be traced down to biological differences but "race" in discourse is inclined to refer to ideology and social structure rather than ethnic origins. Racist ideology inherently exists in society like a hierarchical web interconnecting complicated people from different social groups. It has become a widely acknowledged belief that whites hold a contemptuous attitude towards blacks, colored and yellows; rich yellows look down upon their poorer folks; city-dwelling blacks despise their countryside fellows. Naturally, some people are more susceptible to racist ideology than others and some groups are racist than others. CD analysts do not only describe but also try to explain to illuminate the conditions for the emergence and existence of racism to eradicate it.

Among the many authors who have greatly contributed to CDA as regards discourse racist analysis, Van Dijk can be appreciated as the most influential both in the depth and the diversity of his research. His studies range from panoramic overview on CDA to specific survey data about ethnic attitudes and the way majorities talk to ethnic minority groups. His findings in the projects are absolutely discerning in terms of humanitarian values. The black women in one of his studies "experience accusations of theft, laziness, or dishonesty, are addressed impolitely or patronizingly, or are made sexual propositions in situations where white women would not be harassed" (Van Dijk 1984, 77). In another study, he examines the way in which politicians speak about race and ethnic relations, immigrants, refugees, and other minorities as well as how they contribute - through media coverage of their discourse - to the ethnic consensus in whitedominated society. His analysis of fragments of parliamentary debates about ethnic affairs in Europe and North America shows that "politicians participate in more subtle forms of elite racism when they present immigration and minority relations as essentially problematic, if not threatening, while defining 
refuges, immigrants, or minorities as a main cause of many societal problems" (Van Dijk (1997: 31).

Van Dijk's advocates, following his initiative studies, have raised their voices against social inequality in various forums from a wide range of perspectives and questions. Talbot et al. (2003) e.g. discussed racism in the choice of topics, lexis and sentence structure in the media. They showed that in the reporting of civil disturbances in Brixton, the actions of the police were often placed syntactically in a non-prominent position in the sentence, or by keeping the agency implicit.

Racism in politics in a sense can be said to be the most influential on society, which might be illustrated in the pre-1989 period Soviet Union where opposite concepts as "our socialist people's power versus their bourgeois democracy, our unity versus their pluralism" (Baranov 1998: 131-132) prevailed their propaganda imprints in public political discourse typically transmitted by the media. Thomas (1999) points out the unmarkedness of "us" and the markedness of "them" in British and American press. In one of his investigations, of the five people referred to in the extracts taken from newspapers, the ethnicity of only two is mentioned, that of the "black secretary" and that of the "black inmate" whereas the white ethnicity of the others is left unmarked implicitly indicating their norm and that the minority black group is labeled emphasizing their difference from the mainstream in a context where it is irrelevant.

Research into racism in language education has touched on such aspects of educational life as the use of English as the medium of instruction in schools or the use of language as a requirement for job employment. Bunyi (2001) advances the argument that the use of English as the medium of instruction in Kenyan educational system has prevented children from different socioeconomic backgrounds enjoying equal educational opportunities. She also argues that educational practice and the differential educational treatment of children in Kenya contributes to the reproduction of unequal power relations in Kenyan society. Roberts et. al (1992) raised the issue of language and discrimination in the multi-ethnic workplaces and traced the inequality in employment policies in the UK down to the inequality in admission policies in the UK vocational courses. The authors found out that one single most important criterion for the selection of a course was a certain level of English proficiency and as places available in the work market became scarcer, both course providers and employers raised the levels of English proficiency required. This, according to the authors, has illustrated a well-known paradox that "applicants must already have acquired the skills and resources which qualify them for the opportunities to acquire these skills and resources" (Robert et al, 1992: 328). This paradox has widened the discrimination in the UK educational system.

In summary, CDA has made great contribution to the field of racism with numerous analyses from various approaches shedding light on many issues in different fields from racism in the press, racism in politics, racism in language education, etc.

\subsubsection{Sexism in Language}

In collaboration with racism studies in the fight against social injustice are researches into sexism in language, which are equally diversifying in the questions analyzed. Sexist CDA research encompasses various settings such as in politics, in courtrooms, in advertisements, in the family, in the classroom, etc., and various topics such as women's images and stereotypes in every day conversations or as depicted in the press; deconstructing and reconstructing women's images and stereotypes; and women's struggles and negotiations for connection with men. 
Deconstructing and reconstructing women's images and stereotypes has been the focus of sexist CDA studies. On the whole, contrary to common stereotypes, women in CDA studies used language in a way as to maintain or reinforce rather than destroy their relationships with men. In defiance of common stereotyped assumptions about women's tendency towards talkativeness, West and Zimmerman (1975, 1983, 1985) found out that in intersexual conversations, men's interrupting women occurred far more frequently than women's interrupting men. Kendal and Tannen (1997: 83) reported "in groups, men tend to get and keep the floor more often than women, talk more often and for longer, interrupt more, and make different kinds of contributions, using language strategies that challenge, create and maintain status distinctions (i.e. they create and maintain asymmetrical alignments between themselves and interlocutors). Women, according to this research, "tend to get and keep the floor less frequently and for less time, interrupt less, and use language strategies that are more supportive and that minimize status distinctions". Leto Defransicso (1998) and Tannen (2003) investigated how the power struggle takes place in the family in the process of negotiations for power and negotiations for connection. Leto Defransicso (1998) studied the discursive inequality in the family. Observations of the 7 couples in one of his surveys led him to the conclusion that the men were relatively silent and that their behaviors silenced the women. The noresponse was the most common turn-taking violation, particularly for the men whereas the women worked harder to maintain interaction than the men. In the same vein of research, Krupnick (1985) studied male and female students' practices of turn-taking strategies in the classroom. In her studies, female students do not talk as much as their male peers and are interrupted far more frequently than men are in mixed-sex conversations. One explanation offered by Krupnick is women's extreme vulnerability to interruption. Once interrupted, female students had the tendency to stay out of the conversations for the rest of the class time.

The differentiation between the language including the use of pictures and images describing men and women is also found in advertisements (Nair, 1992; Arima, 2003; Cheng \& Schweitzer, 1996). Men and women are portrayed in advertisements according to the socially constructed stereotypes of femininity and masculinity (Goffman, 1979), in which women have been associated with nature, carnality, instinct and passion whereas men are associated with culture, reason, control and spirituality (Stevens and Ostberg, 2012). The crucial point raised by $\mathrm{CD}$ analysts is that there has been little or no effort by advertising agents in changing these stereotypes to bring about a reversal of men's and women's roles in the media commercials.

Caldas-Coulthard (1995) criticized how men and women are differently described in the press. While male speakers' nominations are modified by their professional designations in public institutions, women are nominated in terms of their marital status, family relations or age. Women's professional statuses are rarely added, and if any, with shorter qualifying or modifying linguistic elements.

Efforts in the fight against socio-political injustice have been continuously made in CDA research and more aspects of social life have been the objects of CDA studies in the field of sexism in language.

\section{Conclusion}

Raising people's awareness of language manipulation is what CDA has effortlessly been doing in the process of constructing a 
more equal society. Research describing and criticizing inequality through language is enormous and so is its impact on individuals and groups as members of our conflicting society. CDA's efforts and achievements in the fight again social inequality have supported the claim that social relations are not fixed but can be changed according to human wills and through human language practices (Krauss \& Chiu, 1997; Butler, 2007). Humans can contribute either to reproducing or to reshaping existing social relations. Language practices are capable of maintaining and reproducing patterns of domination and subordination in society, but $\mathrm{CD}$ analysts, using emancipatory discourse, can fight against this manipulation by raising people's awareness of the asymmetrical relation of power (Janks and Ivanič, 1992), which is also one of the fundamental goals CDA has been attempting to attain.

\section{References}

Arima, A. N. (2003). "Gender stereotypes in Japanese television advertisements." Sex Roles 49, 81-90.

Baranov, A. (1998). "Justice, Equality and Freedom: The Structure of Value Concepts". Chapter 10 in Chilton, P.A., Llyin, M.V., \& Mey, J.L. Political Discourse in Transition Europe 1989-1991. John Benjamins Publishing Company, 131-145.

Bunyi, G. (2001). "Language and Educational Inequality in Primary Classrooms in Kenya". Chapter 4 in Heller, M. \& Martin-Jones, M. Voices of Authority: Education and Linguistic Difference. Ablex Publishing, 77-100.

Butler, J. (2007). Gender Trouble: Feminism and the Subversion of Identity. Routledge.

Caldas-Coulthard, C.R. (1996). Texts and Practices: Readings in Critical Discourse Analysis. Routledge.

Caldas-Coulthard, C.R. (1995). "Man in the News: The Misrepresentation of Women Speaking in News-As-Narrative-Discourse". Chapter 14 in Mills, S. Language and Gender: Interdisciplinary Perspectives. Longman, 226-239.

Cameron, D. (ed.) (1998). The Feminist Critique of Language. Routledge.

Cameron, D. (1992). Feminism and Linguistic Theory. New York: Palgrave Publishers.
Cheng, H., \& Schweitzer J. C. (1996). "Cultural values reflected in Chinese and US television commercials." Journal of Advertising Research, 36, 27-44.

Chilton, P.A., Llyin, M.V., \& Mey, J.L. (1998). Political Discourse in Transition Europe 1989-1991. John Benjamins Publishing Company.

Essed, P. (1991). Understanding Everyday Racism: An Interdisciplinary Theory. Sage.

Fairclough, N. (1992). Critical Language Awareness. Longman

Goffman, E. (1979). Gender advertisements. Cambridge, MA: Harvard University Press.

Janks, H. \& Ivanič, R. (1992). "Critical Language Awareness and Emancipatory Discourse". Chapter 13 in Fairclough, N. Critical Language Awareness. Longman, 305-331.

Kendall, S. \& Tannen, D. (1997). "Gender and Language in the Workplace". Chapter 4 in Wodak, R. Gender and Discourse. Sage, 81-105.

Krauss, R.M. \& Chiu, C. (1997). "Language and Social Behavior". In D. Gilbert, S. Fiske \& G. Lindsey (Eds.), Handbook of social psychology (4h ed.), Vol. 2. (pp. 41-88). Boston: McGraw-Hill.

Krupnick, C.G. (1985). Women and Men in the Classroom: Inequality and Its Remedies. On Teaching and Learning, Volume 1. Derek Bok Center for Teaching and Learning, Harvard University.

Litosseliti, L. (2006). Gender and Language: Theory and Practice. Holder Arnold.

Leto DeFrancisco, V. (1998). "The Sounds of Silence: How Men Silence Women in Marital Relations". Chapter 12 in Coates, J. Language and Gender: A Reader. Blackwell, 176-184.

Nair, R.B. (1992). "Gender, Genre, and Generative Grammar: Deconstructing the Matrimonial Column". Chapter 10 in Toolan, M. Language, Text and Context: Essays in Stylistics. Routledge, 227-254.

Räthzel, N. (1997). "Gender and Racism in Discourse". Chapter 3 in Wodak, R. Gender and Discourse. Sage, 57-80.

Roberts, C., Davies, E., \& Jupp. T. (1992). Language and Discrimination: A Study of Communication in Multi-ethnic Workplaces. Longman.

Schäffner, C. \& Kelly-Holmes, H. (1996). Discourse and Ideologies. Multilingual Matters Ltd.

Stevens, L. M. R. and Ostberg, J. (2012). "Gendered Bodies - Representations of Femininity and Masculinity in Advertising Practices”. In Penaloza, L., Toulouse, N. \& Visconti, L. M. (Eds), Marketing Management: A Cultural Perspective. Routledge, Oxon, 392-407.

Talbot, M., Atkinson, K., \& Atkinson, D. (2003). Language and Power in the Modern World. Edinburgh University Press.

Tannen, D. (2003). "Gender and Family Interaction". Chapter 8 in Holmes, J. \& Meyerhoff, M. (Eds). 
The Handbook of Language and Gender. Blackwell, 179-201.

Tannen, D. (1994). Gender and Discourse: Featuring a New Essay on Talk at Work. OUP

Thomas, L. \& Wareing, S. (1999). Language, Society and Power: An Introduction. Routledge.

Trask, R.L. (2007). Language and Linguistics: The Key Concepts. Routledge.

Van Dijk, T.A. (1984). Pragmatics \& Beyond, Vol. 3, Prejudice in Discourse. John Benjamins Publishing Company.

Van Dijk, T.A. (1997). "Political Discourse and Racism: Describing Others in Western Parliaments". Chapter 2 in Riggins, S.H. The Language and Politics of Exclusion: Others in Discourse. Sage, 31-64.

Van Dijk, T.A. (2001). "Critical Discourse Analysis". Chapter 18 in Schiffrin, D., Tannen, D. \& Hamilton, H.E. (Eds). The Handbook of Discourse Analysis. Blackwell, 352-371.

Widdowson, H.G. (2000). On the Limitations of Linguistics Applied. Applied Linguistics, 211, 3-25.

Wodak, R. (1997). "And Where is the Lebanon?"
A Socio-psycholinguistic Investigation of Comprehension and Intelligibility of News. Text, 7(4), 377-410.

Wodak, R. (2000). "Recontextualization and the Transformation of Meanings: A Critical Discourse Analysis of Decision Making in EU Meetings about Employment Policies". Chapter 11 in Sarangi, S. \& Coulthard, M. Discourse and Social Life. Longman, 185-206.

Zimmerman, D.H. \& West, C. (1975). "Sex Roles, Interruptions and Silences in Conversation" in Thorne, B. \& Henley, N. Language and Sex: Difference and Dominance. Newbury House, 105-29.

Zimmerman, D.H. \& West, C. (1983). "Small Insults: A Study of Interruptions in Cross-sex Conversations between Unacquainted Persons" in Thorne, B., Kramarae, C. \& Henley, N. Language, Gender, and Society. Newbury House, 103-17.

Zimmerman, D.H. \& West, C. (1985). "Gender, Language, and Discourse". In Van Dijk, T.A. Handbook of Discourse Analysis, Vol.4, Discourse Analysis in Society. Academic Press, 103-24.

\title{
TIẾNG NÓI CHỐNG LẠI BÂT CÔNG XÃ HộI TRONG PHÂN TÍCH DIỄN NGÔN PHÊ PHÁN
}

\author{
Huỳnh Anh Tuấn \\ Khoa Sau đại học, Truờng Đại học Ngoại ngũu, ĐHQGHN, Phạm Văn Đồng, Cầu Giấy, Hà Nội, Việt Nam
}

Tóm tắt: Bài báo thảo luận các nghiên cứu thuộc đường hướng phân tích diễn ngôn phê phán trong lĩnh vực diễn ngôn báo chí, diễn ngôn chính trị, diễn ngôn hàm chứa phân biệt chủng tộc và kỳ thị giới tính nhằm lên tiếng chống lại những bất công về chính trị - xã hội. Khảo cứu các nghiên cứu thuộc đường hướng phân tích diễn ngôn phê phán cho thấy số lượng các nghiên cứu thuộc đường hướng này là vô cùng to lớn và có tác động mạnh mẽ đến mọi tầng lớp trong xã hội có những xung đột về quyền lực. Chúng ta có thể đấu tranh chống lại việc sử dụng ngôn ngữ để duy trì và tái tạo sự thống trị và lệ thuộc bằng cách nâng cao nhận thức của mọi người về sự bất bình đẳng trong mối quan hệ quyền lực sử dụng diễn ngôn khai phóng. Đây cũng là một trong những mục tiêu căn bản mà phân tích diễn ngôn phê phán hướng tới.

Từ khóa: phân tích diễn ngôn phê phán, bất bình đẳng về chính trị - xã hội, diễn ngôn báo chí, diễn ngôn chính trị, diễn ngôn phân biệt chủng tộc, diễn ngôn kỳ thị giới tính 